\title{
PENGEMBANGAN LEMBAR KERJA SISWA (LKS) BERBASIS CONTEXTUAL TEACHING AND LEARNING (CTL) MATERI SISTEM PERSAMAAN LINEAR TIGA VARIABEL SISWA KELAS X MIA SMAN 9 KOTA JAMBI
}

\author{
Endah Fitria $^{1}$, Buyung $^{2}$, Aisyah $^{3}$ \\ Pendidikan Matematika FKIP Universitas Batanghari Jambi ${ }^{1,2,3}$ \\ Jl. Slamet Riyadi No.1 Broni Jambi \\ e-mail: -
}

\begin{abstract}
ABSTRAK
Tujuan dari penelitian ini adalah untuk mengembangkan LKS berdasarkan Contextual Teaching and Learning (CTL) pada materi sistem persamaan linear tiga variabel yang valid, praktis dan efektif. Jenis pengembangan penelitian ini adalah Penelitian dan Pengembangan (R\&D) dengan model pengembangan ADDIE terdiri dari analisis, Desain, Pengembangan, Implementasi, Evaluasi. Instrumen penelitian terdiri dari Kuisioner dan instrumen pertanyaan. Kuisioner terdiri dari lembar validasi oleh ahli materi, lembar penilaian validasi oleh pakar desain, lembar penilaian validasi oleh pakar media, lembar evaluasi uji coba individual, lembar evaluasi uji coba kelompok kecil, dan lembar uji lapangan evaluasi. sedangkan instrumen pertanyaan terdiri dari soal pre-test dan post-test. LKS dikembangkan, kemudian divalidasi oleh validator. Hasil validasi diperoleh LKS dengan revisi berdasarkan saran dan komentar validator. Validitas diilustrasikan oleh persentase ahli materi, perancang dan ahli media di 82,61\% dalam kategori "sangat valid", 76,16\% dalam kategori "valid", 90\% dalam kategori "sangat valid". LKS kemudian diujicobakan menjadi tiga tahap: uji coba individu dengan 3 siswa berkemampuan sedang dan rendah, uji coba kelompok kecil dengan 6 siswa, dan uji coba lapangan dilakukan di kelas nyata kelas X MIA 2 dengan 34 siswa. Dilihat dari perbandingan nilai pre-test dan post-test diperoleh thitung 15,37 dan ttabel 2,03 maka thitung > ttabel menyatakan ada perbedaan yang signifikan. Berdasarkan hasil validasi, tes dan tes hasil belajar kemudian diperoleh hasil penelitian yang menunjukkan kelayakan LKS dengan pendekatan CTL tergolong dalam kategori valid, praktis dan efektif.
\end{abstract}

Kata kunci:

Lembar Kerja Siswa, Pengajaran dan Pembelajaran Kontekstual, model pengembangan ADDIE

\begin{abstract}
The purpose of this research is to develop LKS based on Contextual Teaching and Learning (CTL) on linear equation system material three valid, practical and effective variables. This type of research development is Research and Development $(R \& D)$ with the ADDIE development model consist of analysis, Design, Development, Implementation, Evaluation. The research instrument consists of Questionnaire and question instrument. Questionnaires consist of validation sheet by the material expert, validation assessment sheet by design expert, validation assessment sheet by media expert, individualized trial evaluation sheet, small group trial evaluation sheet, and evaluation field test sheet. while the question instrument consists of a pre-test and post-test questions. LKS developed, then validated by the validator. Validation results obtained LKS with revisions based on suggestions and comments validator. Validity is illustrated by the percentage of material expert, designer and media experts in 82,61\% in "highly valid" category, 76,16\% in "valid" category, 90\% in "very valid" category. LKS was then piloted into three stages: individual trials with 3 medium and low-skilled students, small group trials with 6 students, and field trials conducted in the real classroom of class X MIA 2 with 34 students. Judging from the comparison of pre-test and post-test values obtained $t_{\text {count }}$ of 15.37 and $t_{\text {table }}$ of 2.03 then $t_{\text {count }}>t_{\text {table }}$ stated there are significant differences. Based on the results of validation, test and test results of learning then obtained the results of research that shows the feasibility of LKS with CTL approach pertained in categories valid, practical and effective.
\end{abstract}

Keywords:

Student Worksheet, Contextual Teaching and Learning, the development model of ADDIE 


\section{$\pi$ (Phi)}

\section{PENDAHULUAN}

Tercapainya tujuan pembelajaran disekolah adalah hal penting yang perlu diperhatikan oleh tenga pendidik. Beragam cara untuk beragam mata pelajaran pula yang dilakukan untuk membuat tujuan pembelajaran dalam proses pembelajaran tercapai. Salah satunya dalam pembelajaran matematika yang mempunyai cara untuk menyampaikan informasi dengan mengaitkan materi dalam kehidupan seharihari. Seperti halnya pada kutipan BSNP (2006) yang menyebutkan pembelajaran matematika hendaknya dimulai dengan pengenalan masalah yang sesuai dengan situasi kehidupan nyata (contextual problem). Karena, dengan mengajukan masalah kontekstual, peserta didik secara bertahap dibimbing untuk menguasai konsep matematika.

Untuk meningkatkan hasil pembelajaran matematika, diperlukan kegiatan mengembangkan bahan ajar yang digunakan. Bahan ajar merupakan aspek penting dalam proses pembelajaran, karena didalamnya mencakup materi pelajaran yang telah disusun secara sistematis. Salah satu bahan ajar yang digunakan guru untuk mengaktifkan proses pembelajaran adalah Lembar Kerja Siswa (LKS).

Lembar Kerja Siswa (LKS) adalah sarana belajar berupa lembaran-lembaran yang berisi tugas siswa dan latihan-latihan yang telah dikemas sedemikan rupa oleh guru untuk siswanya serta mengacu pada kompetensi dasar untuk mencapai tujuan pembelajaran. LKS digunakan untuk melakukan kegiatan penyelidikan atau pemecahan masalah (Trianto, 2007). Sehingga di dalam LKS yang baik terdapat materi dan tugas yang dibuat sedemikian rupa terstruktur dan sistematis yang dapat membantu siswa dalam memahami konsep materi yang diajarkan serta diharapkan dapat meningkatkan motivasi siswa dalam belajar.Akan tetapi LKS saat ini yang beredar masih bersifat instan tanpa disertai langkah-langkah yang terstruktur dalam menemukan konsep dasar.

Berdasarkan pengamatan di SMAN 9 Kota Jambi, diketahui bahwa LKS yang digunakan dalam proses pembelajaran adalah LKS yang dijual oleh beberapa penerbit. LKS tersebut belum mampu membantu dalam memahami isi materi serta manfaatnya dengan baik. LKS yang diberikan masih berisi kumpulan soal dan materi-materi yang padat. Dilihat dari penyajiannya, LKS terlihat monoton dan kurang menarik dengan tampilan isi yang tidak berwarna dan tanpa tampilan gambar yang menegaskan persoalan yang disajikan, sehingga LKS belum dapat menhidupkan motivasi siswa untuk belajar. Dengan kondisi LKS seperti itu, dampaknya siswa hanya sepintas menerima pengetahuan tanpa tahu akan manfaat dan kegunaan materi matematika dalam konteks kehidupan. Perlu diketahui, LKS berperan penting dalam proses pembelajaran, terutama membantu peserta didik dalam belajar mandiri di rumah melalui materi dan soal-soal yang ada di dalamnya. Agar manfaat LKS dapa dirasakan siswa dengan baik, maka digunakanlah pendekatan Teaching And Learning (CTL) dalam pengembangan LKS. Pendekatan CTL merupakan salah satu alternatif penyelesaian masalah dalam proses kegatan pembelajaran, dimana di dalam penedekatan ini siswa dituntut untuk mencari, mengolah, dan menemukan pengalaman belajar yang lebih bersifat konkret (terkait dengan kehidupan nyata).

LKS berbasis Contextual Teaching And Learning (CTL) diharapkan dapat memotivasi siswa untuk mempelajari materi pada LKS tersebut dan dapat menuntun kepada pengkonstruksian pengetahuan siswa serta menstimulus kemampuan menyelesaikan masalah melalui materimateri dan latihan soal pada SPLTV yang dikaitkan dengan konteks kehidupan nyata. Penyajian isi seperti tugas-tugas dan latihan dalam LKS ini bersifat pemecahan masalah 


\section{$\pi$ (Phi)}

yang berhubungan dengan konteks kehidupan sehari-hari siswa.

Pengembangan LKS berbasis CTL ini bertujuan untuk membangun pemahaman siswa dengan lebih baik, bukan sekedar pemberian materi yang hanya untuk diingat saja. Melainkan dipahami dengan mengkonstruk pemahaman melalui materi dan pertanyaan- pertanyaan yang berkaitan dengan kehidupan sehari-hari. Pada LKS ini siswa diberi kesempatan untuk membentuk pemahamannya melalui pertanyaan awal sebelum memasuki materi yang akan dipelajari.

\section{METODE PENELITIAN}

Penelitian ini merupakan penelitian pengembangan (Research \& Development) yang dirancang untuk menghasilkan produk berupa LKS berbasis Contextual Teaching and Learning (CTL) pada materi sistem persamaan linear tiga variabel siswa kelas X MIA SMAN 9 Kota Jambi. Penelitian ini dilaksanakan pada bulan Agustus sampai September di semester ganjil pada tahun ajaran 2017/2018.

Desain penelitian pengembangan ini mengacu pada model pengembangan ADDIE, meliputi lima tahap yaitu: (1) Tahap Analisis (Analysis), terdiri dari analisis kebutuhan yang meliputi analisis kompetensi, analisis materi, dan analisis karakteristik peserta didik; (2) Tahap Desain (Design), kegiatan yang dilakukan pada tahap desain ini meliputi, persiapan pembuatan produk, penyusunan kerangka dasar LKS, dan penyusunan instrumen penilaian; (3) Tahap Pengembangan (Development), kegiatan pada tahap pengembangan ini pada dasarnya adalah kegiatan menerjemahkan spesifikasi desain kedalam bentuk fisik. Dengan kata lain tahap ini merupakan tahap pembuatan produk. Kemudian pada tahap ini juga dilakukan validasi dan uji coba terhadap LKS. LKS divalidasi oleh 3 pakar yaitu, ahli materi, ahli desain, dan ahli media yang bertujuan untuk mengetahui kualitas LKS pada aspek kevalidan.

Uji coba LKS dilakukan dengan tiga tahap yaitu, uji coba perorangan (one to one leaner), uji coba kelompok kecil (small group try-out), dan uji coba lapangan (field try-out). Uji coba perorangan dan uji coba kelompok kecil dilakukan dengan tujuan untuk menentukan kelayakkan penggunaan LKS pada kelas sesungguhnya, sedangkan uji coba lapangan dilakukan dengan tujuan untuk mengetahui kualitas LKS dari aspek kepraktisannya; (4) Tahap Implementasi (Implementation), kegiatan yang dilakukan pada tahap implementasi ini adalah dengan menyelenggarakan program pembelajaran dengan menggunakan produk yang dikembangkan. Tahap ini bertujuan untuk mengetahui kelayakkan LKS dari aspek keefektifannya; (5) Tahap evaluasi (evaluation), pada umumnya penelitian pengembangan ini hanya menggunakan evaluasi formatif saja, dimana evaluasi formatif ini berfungsi untuk memperbaiki LKS di setiap tahapnya, mulai dari analisis, desain, pemngembangan dan implementasi.

Data yang diperoleh dari penelitian ini berupa data kuantitatif dan data kualitatif. Data kuantitatif yang diperoleh berupa skor rata-rata yang kemudian dikonversi menjadi nilai kualitatif sesuai kriteria penilaian Widoyoko (2015:238). Data kuantitatif tersebut diperoleh dari: (1) hasil validasi LKS oleh validator (2) hasil angket penilaian oleh siswa; (3) hasil selisih dari nilai pre-test dan post-test. Dalam pengumpulan ketiga data tersebut digunakan beberapa instrumen penelitian, yaitu (1) Lembar validasi dan evaluasi LKS; (2) lembar validasi soal; dan (3) tes hasil belajar siswa.

Data kualitatif diperoleh dari masukkan atau tanggapan dari para ahli melalui pengisian angket validasi. Datadata tersebut dianalisis secara deskriptif kualitatif. Tanggapan atau masukan dari para ahli yang bersifat membangun dan dianggap tepat untuk pengembangan 


\section{$\pi$ (Phi)}

perangkat pembelajaran digunakan sebagai bahan perbaikan pada tahap revisi perangkat pembelajaran.

\section{HASIL DAN PEMBAHASAN}

Hasil penelitian ini membahas tentang penyajian hasil di setiap tahap pada model yang digunakan dalam mengembangkan LKS berbasis contextual teaching and learning untuk SMA kelas X, yakni model ADDIE. Tahap pada model ADDIE terdiri dari tahap analisis (analysis), tahap desain (design), tahap pengembangan (development), tahap implementasi (implementation) dan tahap evaluasi (evaluation).

Tahap analisis (analysis) meliputi analisis kompetensi, analisis materi dan analisis karakteristik peserta didik. Pada tahap ini diperoleh dengan observasi langsung dan wawancara terhadap guru matematika di SMAN 9 Kota Jambi. Dari hasil observasi langsung diketahui kurikulum yang digunakan di SMAN 9 adalah kurikulum 2013 revisi 2016. Sedangakan dari hasil wawancara terhadap guru matematika diketahui materi sistem persamaan linear tiga variabel dapat disampaikan melalui pembelajaran berbasis CTL, karena materi ini dapat dikaitkan dengan kehidupan sehari-hari. Disamping itu dapat pula diketahui bahwa karakteristik siswa SMAN 9 berbeda-beda, ada siswa dengan karakter dapat berfikir logis tentang gagasan abstrak pada matematika, dan ada juga yang belum dapat berfikir logis tentang gagasan abstrak pada matematika. Hal ini diperkuat oleh hasil wawancara terhadap guru matematika bahwa sebagian siswa belum dapat mengubah masalah ke dalam bentuk matematika.

Tahap desain (design) meliputi persiapan pembuatan produk, penyusunan kerangka dasar LKS dan penyusunan instrument penilaian. Pada tahap ini dilakukan dengan mengumpulkan sumbersumber bahan ajar sebagai acuan pembuatan kerangka dasar LKS yang terdiri dari, cover, kata pengantar, daftar isi, petunjuk penggunaan LKS, peta konsep, $\mathrm{KI}, \mathrm{KD}$, indikator pencapaian kompetensi, tampilan awal materi yang disesuaikan dengan pendekatan CTL, latihan siswa, penilaian autentik dan daftar pustaka. Tahap desain ini dilakukan juga dengan membuat lembar penilaian angket yang ditujukan kepada telaah pakar dan siswa serta membuat tes hasil belajar siswa untuk mengukur keefektifan LKS.

Tahap pengembangan (development) merupakan penjabaran dari spesifikasi produk yang dihasilkan. Kegiatan palada tahap ini diawali dengan pembuatan produlk LKS yang kemudian dilakukan validasi dan revisi. Adapun hasil validasi LKS dapat dilihat pada Tabel 1.

Berdasarkan rekapitulasi hasil validasi oleh validator, diperoleh persentase keseluruhan validasi oleh ahli materi $82,62 \%$, persentase keseluruhan validasi oleh ahli desain $78 \%$, dan persentase keseluruhan validasi oleh ahli media $90 \%$. Maka berdasarkan kriteria kevalidan (Akbar, 2013:14) validasi oleh ahli materi dan ahli media dinyatakan sangat valid. Sedangkan validasi oleh ahli desain dinyatakan valid. Sehingga LKS berbasis CTL dinyatakan valid dengan revisi.

Tabel 1. Rekapitulasi Hasil Validasi Pakar

\begin{tabular}{clcc}
\hline $\begin{array}{c}\text { Telaah } \\
\text { Pakar }\end{array}$ & Aspek yang dinilai & $\begin{array}{c}\text { Skor } \\
\text { rata- } \\
\text { rata }\end{array}$ & $\begin{array}{c}\text { \% } \\
\text { Keseluru } \\
\text { han }\end{array}$ \\
\hline \multirow{2}{*}{ Ahli } & Kelayakkan isi & 4,14 & \\
materi & Kebahasaan & 4,25 & $82,62 \%$ \\
& Sajian & 4 & \\
\hline \multirow{4}{*}{ Ahli } & Constructivism & 3 & \\
& Questioning & 4 & \\
& Inquiry & 3 & \\
& Learning & 4 & \\
& Modelling & 4 & $78 \%$ \\
& Reflection & 4 & \\
& Authentic & 4 & \\
& Assesment & & \\
& Kelengkapan & 4,3 & \\
& komponen & & \\
\hline Ahli & Tampilan & 4,5 & $90 \%$
\end{tabular}




\section{$\pi$ (Phi)}

\begin{tabular}{llcc}
\hline $\begin{array}{l}\text { Telaah } \\
\text { Pakar }\end{array}$ & Aspek yang dinilai & $\begin{array}{c}\text { Skor } \\
\text { rata- } \\
\text { rata }\end{array}$ & $\begin{array}{c}\text { \% } \\
\text { Keseluru } \\
\text { han }\end{array}$ \\
\hline Media & $\begin{array}{l}\text { Layout atau tata } \\
\text { letak }\end{array}$ & 4,5 & \\
& Penggunaan font & 4,3 & \\
& Mutu gambar & 4,5 & \\
& Perwajahan & 4,6 & \\
\hline
\end{tabular}

Tahap

(implementation) dilakukan dengan kegiatan uji coba LKS dan implementasi kepada kelas sesungguhnya. Uji coba LKS dilakukan pada 3 tahap, yaitu uji coba perorangan, uji coba kelompok kecil, uji coba lapangan. Uji coba dilakukan dengan tujuan untuk mengetahui kepraktisan LKS.

a) Uji Coba Perorangan

Uji coba perorangan dilakukan oleh siswa pada 3 kelas berbeda, yaitu kelas $\mathrm{X}$ MIA1, $\mathrm{X}$ MIA 2, dan X MIA 3 . Masing-masing kelas dipilih satu siswa dengan tingkat kemampuan yang berbeda. Pengambilan siswa dengan tingkat kemampuan yang berbeda itu didasarkan pada nilai siswa dan juga hasil wawancara guru matematika. Peneliti mengambil siswa dengan kemampuan tinggi pada kelas X MIA 1, siswa dengan kemampuan sedang pada kelas X MIA 2, dan siswa dengan kemampuan rendah pada kelas $\mathrm{X}$ MIA 3. Hasil dari uji coba perorangan diketahui rata-rata keseluruhan adalah 4,48 yang dikategorikan sangat baik. Selain itu dapat pula diketahui kriteria penilaian per aspeknya. Berikut disajikan diagram batang hasil penilaian evaluasi pada uji coba lapangan

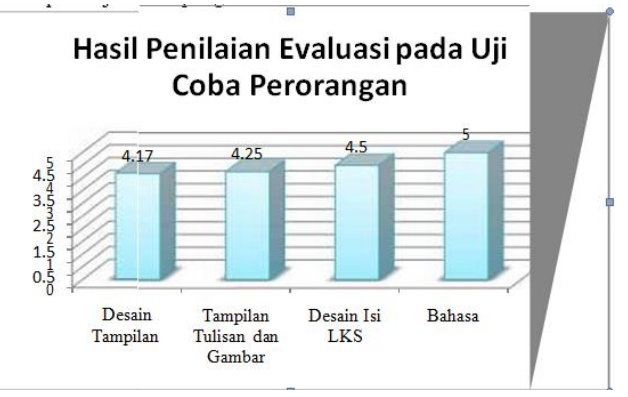

Diagram 1. Hasil Penilaian Evaluasi pada Uji Coba Perorangan
Berdasarkan diagram batang di atas dapat diuraikan (1) aspek desain tampilan dengan rata-rata skor 4,17 dengan kriteria baik (2) aspek tampilan tulisan dan gambar dengan rata-rata skor 4,25 dengan kriteria sangat baik (3) aspek desain isi LKS dengan rata-rata skor 4,50 dengan kriteria sangat baik, dan (4) aspek bahasa dengan rata-rata skor 5 dengan kriteria sangat baik. Presentase keseluruhan aspek yaitu $87 \%$ sehingga kelayakkan LKS dikategorikan sangat layak.

b) Uji Coba Kelompok Kecil

Berdasarkan diagram batang diatas dapat diuraikan (1) aspek desain tampilan dengan rata-rata skor 3,92 dengan kriteria baik (2) aspek tampilan tulisan dan gambar dengan rata-rata skor 4,08 dengan kriteria baik (3) aspek sajian isi LKS dengan rata-rata skor 4,13 dengan kriteria baik. Presentase keseluruhan aspek yaitu $81 \%$ sehingga kelayakkan LKS dikategorikan sangat layak.

c) Uji Coba Lapangan

Hasil uji coba lapangan adalah sebagai berikut:

(1) aspek desain tampilan dengan ratarata skor 3,71 dengan kriteria baik.

(2) aspek tampilan tulisan dan gambar dengan rata-rata skor 4,05 dengan kriteria baik

(3) aspek sajian isi LKS dengan rata-rata skor 4,12 dengan kriteria baik

(4) aspek sajian isi LKS dengan rata-rata skor 4,02 dengan kriteria baik

(5) aspek sajian isi LKS dengan rata-rata skor 4,16 dengan kriteria baik

(6) aspek sajian isi LKS dengan rata-rata skor 4,39 dengan kriteria baik

Presentase keseluruhan aspek yaitu 84\% kelayakkan LKS sehingga dikategorikan sangat layak.

Setelah LKS dinyatakan valid dan praktis, LKS berbasis CTL diimplementasikan di kelas sesungguhnya, yaitu kelas X SMAN 9 Kota Jambi, dengan 


\section{$\pi$ (Phi)}

jumlah siswa 34 orang. LKS tersebut diujicobakan pada tanggal 6 September 2017 sampai 27 September 2017 dengan 5 kali pertemuan membahas LKS dan 2 kali pertemuan untuk dilaksanakannya pre-test dan post-test.

Hasil pelaksanaan pre-test dan posttest, diketahui t hitung sebesar 15,37 dan $\mathrm{t}$ table sebesar 2,03 sehingga t hitung $>\mathrm{t}$ table yang berarti hipotesis diterima dan dinyatakan terdapat perbedaan yang signifikan antara pre-test dan post-test. Sehingga LKS dinyatakan efektif.

Berdasarkan uraian tersebut disimpulkan bahwa bahan ajar berupa Lembar Kerja Siswa (LKS) matematika kelas X materi sistem persamaan linear tiga variabel dengan pendekatan Contextual Teaching and Learning (CTL) memiliki kualitas valid, praktis dan efektif. Penelitian pengembangan ini terdapat beberapa keterbatasan penelitian diantaranya: (1) penelitian pengembngan ini hanya dilaksanakan di satu sekolah yaitu sekolah Menengah Atas Negeri 9 Kota Jambi; (2) biaya yang dikeluarkan selama proses pembuatan lembar kerja siswa cukup besar; (3) LKS yang dihasilkan masih termasuk pengembangan tingkat pemula yang hanya mencakup satu bab materi yaitu sistem persamaan linear tiga variabel; (4) LKS hanya dinilai oleh 1 ahli materi, 1 ahli media, 1 ahli desain, serta berdasarkan respon dari satu kelas pembelajaran siswa SMA.

\section{SIMPULAN DAN SARAN}

Berdasarkan hasil penelitian pengembangan yang dilakukan maka diperoleh kesimpulan: (1) berdasarkan hasil validasi LKS berbasis CTL yang telah dilakukan kepada 3 orang validator, yang masing- masing sebagai ahli materi, ahli media, dan ahli desain didapat persentase keseluruhan 82,62\%; 78\%; 90\% yang menunjukkan LKS berbasis CTL dinyatakan valid setelah dilakukan beberapa revisi dan perbaikkan. (2) berdasarkan hasil uji coba LKS berbasis CTL didapat persentase keseluruhan uji coba perorangan, uji coba kelompok kecil, dan uji coba lapangan yaitu $87 \%, 81 \%, 84 \%$ yang menunjukkan LKS berbasis CTL dinyatakan praktis. (3) berdasarkan hasil pelaksanaanpre- test dan post-test didapat $t_{\text {hitung }}(\mathrm{t})$ sebesar 15,37 dan $\mathrm{t}$ tabel $\left(\mathrm{t}_{0}\right)$ sebesar 2,03 sehingga $t>t_{0}$ yang berarti hipotesis diterima dan dinyatakan terdapat perbedaan yang signifikan antara post-test dan pre-test. Atau dengan kata lain LKS dinyatakan efektif.

Berdasarkan kelayakkan LKS, kelemahan dan keterbatasan dalam penelitian yang dilakukan oleh peneliti, terdapat beberapa saran pemanfaatan dan pengembangan LKS lebih lanjut, diantaranya (1) LKS berbasis CTL ini masih perlu dikembangakan lagi terutama dalam hal penyajian materi yang lebih luas, artinya tidak hanya memuat satu materi pelajaran saja namun bisa 2dua atau tiga materi, agar penggunaan LKS dapat memaksimalkan kegiatan pembelajaran. (2) untuk penelitian selanjutnya diharapkan uji coba tidak hanya dilakukan di satu sekolah dan di satu kelas saja, namun ujicoba sebaiknya lebih dari satu kelas atau lebih dari satu sekolah sehingga dapat menghasilkan LKS yang bisa digunakan secara luas.

\section{DAFTAR PUSTAKA}

Amri,S. Dan Ahmadi, L.K. 2010. Konstruksi Pengembangan Pembelajaran. Jakarta: PT. Prestasi Pustaka Raya.

Aqib, Zainal. 2014. Model-model, Media, dan Strategi Pembelajaran Kontekstual (Inovatif). Bandung: YramaWidya.

Belawati, dkk. 2007. Pengembangan Bahan Ajar. Jakarta: Universitas Terbuka.

Depdiknas. 2008. Panduan Pengembangan Bahan Ajar. Jakarta: Depdiknas.

Djaalidan Mujono, P. 2008. Pengukuran dalam Bidang Pendidikan. Jakarta: PT Grasindo. 
Hanafiah, N, dan Suhana, C. 2009. Konsep Strategi Pembelajaran. Bandung: PY. RefikaAditama.

Hidayat, Nir. 2014. Pengembangan Modul Matematika dengan Pendekatan Kontekstual pada SMP Kelas VIII Materi SPLDV. Yogyakarta: UIN SUKA.

Komalasari, Kokom. 2010. Pembelajaran Kontekstual Konsep dan Aplikasi. Bandung: RefikaAditama.

Lestari, Ika. 2013. PengembanganBahan Ajar Berbasis Kompetensi (Sesuai dengan Kurikulum Tingkat Satuan Pendidikan). Padang: Akademia.

Prastowo, Andi. 2011. Panduan Kreatif Membuat Bahan Ajar Inovatif. Yogyakarta: DIVA Press.

Pribadi, Benny A. 2010. Model Desain Sistem Pembelajaran. Jakarta: Dian Rakyat.

Sanjaya, Wina. 2006. Strategi Pembelajaran Berorientasi Standar Proses Pendidikan. Jakarta: Kencana Prenada Media Group.

Shoimin, Aris. 2014. 68 Model Pembelajaran Inovatif dalam Kurikulum 2013. 2014: Ar-Ruzz Media.

Sudjana, Nana. 2005. Metoda Statistika. Bandung: PT. Tarsito Bandung. Sugiyono. 2013. Metode Penelitian Pendidikan Pendekatan Kuantitatif, Kualitatif, dan $R \& D$. Bandung: Alfabeta.

Supardi. 2014. Aplikasi Statistika dalam Penelitian Konsep Statistika yang Lebih Komprehensif. Jakarta: Change Publication.

Suprijono, Agus. 2011. Cooperative Learning. Yogyakarta: Pustaka Belajar.

Tegeh, dkk. 2014. Model Penilitian Pengembangan. Yogyakarta: Graha Ilmu

Tim Pengembang MKPD Kurikulum dan Pembelajaran. 2012. Kurikulum dan Pembelajaran. Jakarta: Rajawali Pers.

Trianto. 2007. Model Pembelajaran Terpadu dalam Teori dan Praktek. Surabaya: Kencana Prenada Media Group. 